\title{
Article \\ Robust Recombinant Expression of Human Placental Ribonuclease Inhibitor in Insect Cells
}

\author{
Beáta Flachner, Krisztina Dobi, Anett Benedek, Sándor Cseh, Zsolt Lőrincz * and István Hajdú *(D) \\ TargetEx Ltd., Madách I. u. 31/2., H-2120 Dunakeszi, Hungary; flachner@targetex.com (B.F.); \\ dobi@targetex.com (K.D.); benedek@targetex.com (A.B.); cseh@targetex.com (S.C.) \\ * Correspondence: lorincz@targetex.com (Z.L.); hajdu@targetex.com (I.H.)
}

check for updates

Citation: Flachner, B.; Dobi, K.; Benedek, A.; Cseh, S.; Lőrincz, Z.; Hajdú, I. Robust Recombinant Expression of Human Placental Ribonuclease Inhibitor in Insect Cells. Biomolecules 2022, 12, 273. https://doi.org/10.3390/ biom 12020273

Academic Editors: Zdenko Levarski and Stanislav Stuchlík

Received: 27 December 2021

Accepted: 3 February 2022

Published: 8 February 2022

Publisher's Note: MDPI stays neutral with regard to jurisdictional claims in published maps and institutional affiliations.

Copyright: (C) 2022 by the authors. Licensee MDPI, Basel, Switzerland. This article is an open access article distributed under the terms and conditions of the Creative Commons Attribution (CC BY) license (https:// creativecommons.org/licenses/by/ $4.0 /)$.

\begin{abstract}
Ribonuclease inhibitors (RIs) are an indispensable biotechnological tool for the detection and manipulation of RNA. Nowadays, due to the outbreak of COVID-19, highly sensitive detection of RNA has become more important than ever. Although the recombinant expression of RNase inhibitors is possible in E. coli, the robust expression is complicated by maintaining the redox potential and solubility by various expression tags. In the present paper we describe the expression of RI in baculovirus-infected High Five cells in large scale utilizing a modified transfer vector combining the beneficial properties of Profinity Exact Tag and pONE system. The recombinant RI is expressed at a high level in a fusion form, which is readily cleaved during on-column chromatography. A subsequent anion exchange chromatography was used as a polishing step to yield $12 \mathrm{mg}$ native RI per liter of culture. RI expressed in insect cells shows higher thermal stability than the commercially available RI products (mainly produced in E. coli) based on temperature-dependent RNase inhibition studies. The endotoxin-free RI variant may also be applied in future therapeutics as a safe additive to increase mRNA stability in mRNA-based vaccines.
\end{abstract}

Keywords: ribonuclease inhibitor; quantitative PCR; baculovirus-insect expression system; high-level soluble expression

\section{Introduction}

Ribonuclease inhibitors are a $50 \mathrm{kDa}$ cysteine and leucine-rich repeat protein found in the cytosol of cells in most mammalian species. RI is a potent inhibitor of the ribonuclease A (RNase A) superfamily, inhibiting RNase A activity with an extremely low Ki value of $4 \times 10^{-14} \mathrm{M}$ at a molar ratio of $1: 1$.

RNase $\mathrm{A}$ is one of the most prominent causes of contamination both in genetic engineering and in diagnostic polymerase chain reaction (PCR)-based approaches. As RNase $A$ is a very stable and robust enzyme, its total inhibition is required in most cases. The recombinant expression of mammalian RIs represents a very challenging task: its amino acid composition, especially the 28-32 cysteines (the number varies between different species), which must be kept in a reduced form to maintain enzymatic activity. Furthermore, its fold, characterized by alternating units of an $\alpha$-helix and $\beta$-strand forming a striking horseshoe shape [1], also requires a proper folding machinery. Previous data indicate that although RI could be expressed in E. coli [2-5] and S. cerevisiae [6] and D. melanogaster [7], the robust production of RI requires special expression constructs and conditions.

The oxidation state of RI is a critical factor. All cysteines must be in a reduced form for activity and in the free form the cysteines cooperatively form disulfide bridges [8]. After initial oxidation of a small number of cysteine residues, a conformational change occurs, resulting in the cooperative formation of 15 disulfide bonds that leads to the inactivation of the porcine RI. Disseminating the role of individual cysteine residues, it was shown that Cys328 and Cys329 of human RI is mainly responsible for the initiation of oxidation and their mutation to alanine significantly decreases the sensitivity of RI towards oxidation [9]. 
RI was originally purified from placenta [10], while the first recombinant RI (porcine) in an active form was expressed in S. cerevisiae [6], at a low yield $(0.2 \mathrm{mg}$ recombinant protein/g wet cells). The first successful attempt to express RI in E. coli yielded $0.25 \mathrm{mg}$ RI/L culture in 1989 [11]. The solubility of RI is very low and its expression in E. coli often leads to inclusion bodies. Later modification of the expression procedure led to higher yields: $15 \mathrm{mg} / \mathrm{L}$ culture [3] for porcine RI. Addition of the reducing agent dithiotreitol (DTT), low production temperature and co-expression of the chaperonin GroELS resulted in high level production using the conditions with the EnBase ${ }^{\circledR}$ technology $[5,12]$. Another promising attempt was to use $\mathrm{N}$-terminal tags to increase the solubility of RI. Three protein tags: maltose binding protein (MBP), N-utilization substance A (NusA) and translation initiation factor 2 domain I (IF2) have improved the solubility of murine RI, enhancing the recombinant protein yield to $24-34 \mathrm{mg} / \mathrm{L}$ culture [4]. Expression of RI in insect cells was also accomplished in stably transfected $D$. melanogaster cells to yield $1.4 \mathrm{mg} / \mathrm{L}$ recombinant human RI [7]. Although several methods were published for the expression of RI, these processes require special conditions or a multi-step purification streamline with addition cleavage of tags, which make them hardly reproducible in common laboratories.

Currently with the continuous spreading of COVID-19 and the discovery of new variants $[13,14]$, the need for diagnostic PCR consumables rapidly increases and therefore sufficient quantity of RI is highly demanded. To minimize the occurrence of false test results, the stability of all components of the diagnostic tests, including RI, should be maximized. The E. coli derived "hard to produce" recombinant proteins often have small conformational inaccuracies mainly at the termini, which make these proteins less stable than their native counterparts. In our work, we focused on the expression of RI in the Baculovirus Expression Vector System (BEVS) system where the chance of correct folding and producing more stable proteins is significantly higher than in E. coli.

\section{Materials and Methods}

\subsection{Materials}

All chemicals used in the highest commercially available purity. For DNA manipulation, enzymes were purchased from NEB, the synthetic gene was produced at GeneArt (Thermo Fisher, Waltham, MA, USA). Media for recombinant protein expression was purchased from Thermo Fisher (Waltham, MA, USA). Chromatography cartridges and media were purchased from Bio-Rad (Hercules, CA, USA) and Cytiva (Washington, DC, USA). Cell lines Sfg and High Five were purchased from Thermo Fisher (Waltham, MA, USA), and Sf-9 ET from Kerafast (Boston, MA, USA).

\subsection{Transfection, Virus Propagation and Protein Expression}

Recombinant RI was expressed in baculovirus/insect cell expression system [15], which is based on the co-transfection of insect cells with linearized Autographa californica multiple-capsid nuclear polyhedrosis virus (AcMNPV) baculovirus DNA and a transfer plasmid carrying the gene of interest, for the construction of baculovirus vectors. Sfg cells were co-transfected with the previously constructed expression contained the gene for the fused ribonuclease inhibitor gene in pOPal30 vector and flashBAC GOLD (Oxford Expression Technologies) in a $35 \mathrm{~mm}$ Petri dish. To obtain $\mathrm{p} 1$ and $\mathrm{p} 2$ virus stocks, virus infections were conducted over a 7-day period in T75 and T175 flasks, respectively. To obtain a larger amount of viruses for high scale expression, propagation was transferred into shaking flasks. A $180 \mathrm{~mL}$ volume of $S f 9$ cell culture was grown in $500 \mathrm{~mL}$ flasks to $2 \times 10^{6} / \mathrm{mL}$ density with at least $80 \%$ viability. Cells were infected using a multiplicity of infection (MOI) [16] of 0.1 and grown for a further 4 days at $110 \mathrm{rpm}$ agitation at 27 degrees. To quantify the titer of the newly produced virus, stock Sf9 Easy Titer Cell Line (Sf-9 ET) was used as suggested [17].

High Five cells were infected with an MOI of 0.05 of the virus stock at a cell density of $2 \times 10^{6} / \mathrm{mL}$ using $2500 \mathrm{~mL}$ in each $5 \mathrm{~mL}$ shaked flask. Flasks were agitated at $90 \mathrm{rpm}$ at 
$27^{\circ} \mathrm{C}$. After $1 \mathrm{~h}, 1 \%(v / v)$ of $50 \mathrm{mg} / \mathrm{mL}$ bovine serum albumin (BSA) stock solution was added to the cultures and the flask was incubated for further $95 \mathrm{~h}$.

\subsection{Purification of $R I$}

At the end of production, the whole fermentation culture was sonicated using Bandelin SONOPULS ultrasonic sonicator equipped with VS70T probe for $5 \mathrm{~min}$ at $70 \%$ intensity with $60 \%$ cycle parameter. The homogenized culture was filtered through an $0.45 \mu \mathrm{m}$ cellulose acetate filter. The filtered culture was applied to Profinity Exact column, washed with $100 \mathrm{mM}$ sodium-phosphate buffer ( $\mathrm{pH}$ 7.2) and eluted with $100 \mathrm{mM}$ sodium-phosphate, $100 \mathrm{mM}$ sodium-fluoride ( $\mathrm{pH}$ 7.2) buffer. For efficient cleavage of the tag, the flow was stopped for $40 \mathrm{~min}$ before the collection of the eluted fractions.

The eluted fractions containing RI were collected and subjected to a Q Sepharose Fast Flow anion exchange column in the original elution buffer. After sample load, the column was washed with $40 \mathrm{mM}$ Hepes ( $\mathrm{pH} 7.2$ ) and $40 \mathrm{mM}$ Hepes, $150 \mathrm{mM}$ sodiumchloride ( $\mathrm{pH} 7.2$ ) until equilibrium. The concentrated RI was eluted with $40 \mathrm{mM}$ Hepes, $1 \mathrm{M}$ sodium-chloride ( $\mathrm{pH}$ 7.2).

The eluted protein was subsequently gel filtrated through a Sephadex G-25 Medium column in $40 \mathrm{mM}$ Hepes, $100 \mathrm{mM}$ sodium-chloride ( $\mathrm{pH}$ 7.5) buffer. After elution, $16 \mathrm{mM}$ DTT and equal volume of glycerol was added to result a $20 \mathrm{mM}$ Hepes, $50 \mathrm{mM}$ sodium chloride $8 \mathrm{mM}$ DTT, $50 \%$ glycerol ( $\mathrm{pH}$ 7.2) storage buffer for ribonuclease inhibitor. For extended storage, the protein solution was stored at $-20^{\circ} \mathrm{C}$.

\subsection{Temperature Dependent RNase Activity Measurements}

Activity measurements are based on the degradation of total RNA by bovine RNase A. Total RNA was isolated from 3T3 mouse cell line using a Monarch Total RNA preparation kit. RI $(0.5 \mathrm{mg})$ was incubated at the indicated temperatures for $30 \mathrm{~min}$ before adding to the mix (RNase A 5 pg, RNA $2 \mu$ g, buffer: $100 \mathrm{mM}$ Tris, $1.2 \mathrm{mM}$ EDTA, $0.1 \mathrm{mg} / \mathrm{mL}$ BSA, $8 \mathrm{mM}$ DTT (pH 7.5). Samples were then incubated at $37^{\circ} \mathrm{C}$ for $30 \mathrm{~min}$ (to allow RNase to degrade RNA, if active), $6 \times$ Loading Dye was added to stop the reaction, and then loaded on $1.2 \%$ agarose e-gel. Degradation of RNA was analyzed after imaging with Bio-Rad Gel Doc EZ Imager (Hercules, CA, USA).

\subsection{DSF Measurements}

Temperature-induced unfolding of the proteins was examined by Thermal Shift Assay [18] in a Bio-Rad CFX 96 qPCR equipment based on the differential binding of Sypro Orange fluorescent dye to native and unfolded proteins. For the measurements, all ribonuclease inhibitors were diluted to $0.05 \mathrm{mg} / \mathrm{mL}$ concentration in $50 \mathrm{mM}$ sodium-phosphate, $50 \mathrm{mM}$ sodium-chloride ( $\mathrm{pH}$ 7.5) containing a 1000-fold dilution of Sypro Orange. For the studies in the presence of RNase, bovine RNase A was added in an equimolar ratio with RI. Unfolding was followed between $30-90{ }^{\circ} \mathrm{C}$ using a $1{ }^{\circ} \mathrm{C} / \mathrm{min}$ gradient. Thermal unfolding was defined as the negative peak of the first derivative of the fluorescence curve measured using the FRET channel of the qPCR equipment.

\section{Results and Discussion}

\subsection{Design of Expression Plasmid}

The vector design for the recombinant expression of RI in insect cells is based on two previous vector systems: the Profinity Exact system [19], which utilizes an immobilized, engineered, fluoride triggered subtilisin [20] that both recognizes and avidly binds to the small N-terminal co-expressed affinity tag in a protein fusion; and pONE [21] in which the baculovirus transfer vector (pONE30A) is optimized to yield high protein quantity as a fusion protein. An insect cell codon optimized version of the fusion section of pPal8 was introduced to pONE30A at NdeI/NotI sites to create a new baculovirus transfer vector named pOPal30 compatible with the original Profinity Exact system. A codon-optimized version of the human placental ribonuclease gene was subcloned into pOPal30 using BamHI 
and NotI sites. The sequence of ribonuclease gene contained two mutations previously identified as the main cause of oxidation resistance: Cys328Ala and Cys329Ala [9]. The sequence of the expression plasmid was verified by sequencing and used for co-transfection of Sf9 with flashBAC GOLD genetically optimized $A$. californica nucleopolyhedrovirus DNA [22].

\subsection{Expression of $R I$}

The expression of RI in High Five cells was originally established in $500 \mathrm{~mL}$ shaker cultures using $125 \mathrm{~mL}$ medium using different starting cell density in the range of $1.5-3 \times 10^{6} / \mathrm{mL}$. Our results showed that the highest amount of recombinant protein could be obtained at $2 \times 10^{6} / \mathrm{mL}$ cell density. In the $500 \mathrm{~mL}$ flasks we optimized the medium level to reach the highest possible amount at $180 \mathrm{~mL}$ based on the works of Rieffel et al. [23]. The effect of MOI on the expression level was investigated in the range of $0.01-0.05$ and we concluded that 0.05 was the optimal ratio.

The further stage of upscaling of the production was the use of $5 \mathrm{~L}$ shaking flasks with 1800-2500 mL medium. The highest amount of RI could be harvested after $96 \mathrm{~h}$, however, as cells partially lysed, proteases degraded the recombinant protein. To confine this proteolytic effect, bovine serum albumin (BSA) was used as a bait for proteases at $0.5 \mathrm{mg} / \mathrm{mL}$ starting concentration. The time of addition for BSA was also optimized and we found that its addition after only $1 \mathrm{~h}$ after infection worked optimally.

\subsection{Purification}

Recombinant RI was harvested after $96 \mathrm{~h}$, with the protein found both in the supernatant of cells and within cells. We attempted to purify the protein from both sources after centrifugation and work with both fractions individually. From the precipitate the recombinant protein could be retrieved with low efficiency, hence we omitted the centrifugation step. We used a gentle ultrasound sonication step for cell disruption from the whole cell culture including media and centrifuged it only after the disruption step.

The cleared lysed culture was applied to Profinity Exact columns in halogen-free extraction medium. After applying the whole sample to the column, one column volume elution buffer was applied, and the flow was stopped for $40 \mathrm{~min}$ at room temperature. After the incubation time, the cleaved protein was eluted with the fluoride-containing elution buffer.

The second step of purification is an anion exchange ( $Q$ Sepharose Fast Flow), which serves as a three-headed tool: elimination of protein impurities; elimination of host cell DNA and a concentration step. We managed to elute the protein of interest at $5-10 \mathrm{mg} / \mathrm{mL}$ concentration in DNA-free form. As a final step, buffer exchange was executed on a Sephadex G-25 column. The final protein was at least 95\% pure as visualized on SDS-PAGE (Figure 1).

To quantify the volumetric production of RI, we repeated the expression/purification process several times. The yield of the individual expression of sixteen cycles is shown in Supplementary Table S1. We determined the number of cells, the volumetric yield and yield related to number of infected cells for each cycle. The volumetric yield is $12.4 \pm 3.7 \mathrm{mg} / \mathrm{L}$ culture, while it corresponds to $3.6 \pm 1.1 \mathrm{mg} / 10^{9}$ insect cells. The yield is well comparable to that shown in the case of porcine RI in E. coli [3]. 


\section{MW RI}

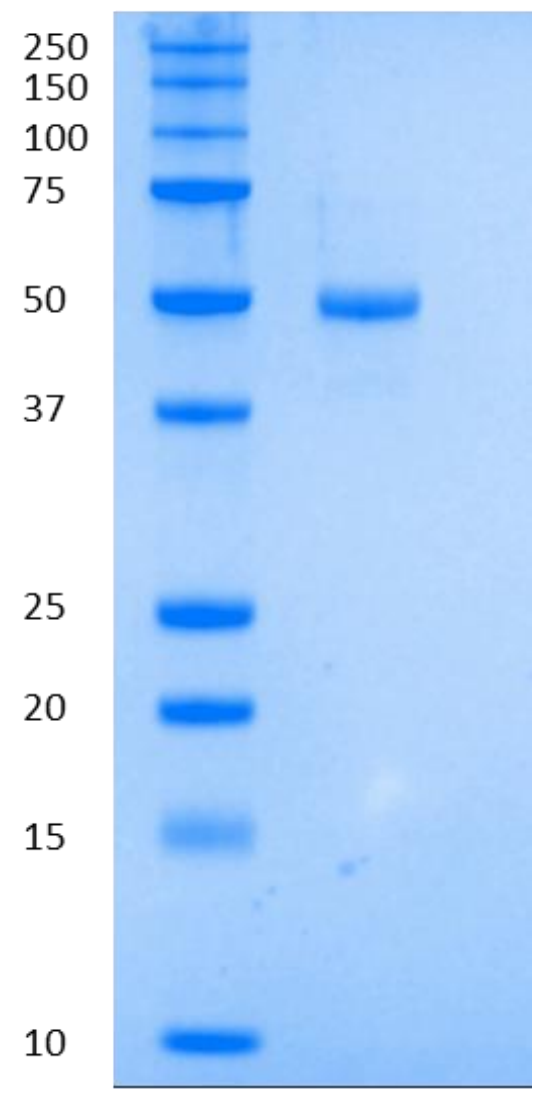

Figure 1. Purified RI run on SDS-PAGE.

\subsection{Heat Stability of RI}

The activity of RI was compared to four RIs available from commercial sources. RNase activity was investigated using the RI variants previously incubated at 60; 62.5; 65; and $67.5^{\circ} \mathrm{C}$. As a negative control a 'no RI' and for positive control not-incubated RI was used. Figure 2 shows that RI expressed in insect cells was able to inhibit RNase completely until $65^{\circ} \mathrm{C}$ and partially at $67.5^{\circ} \mathrm{C}$. 'RI III' and 'RI IV' are fully active until $65^{\circ} \mathrm{C}$, but completely inactive after preincubation at $67.5^{\circ} \mathrm{C}$. ' $\mathrm{RI} \mathrm{I}$ ' is fully inhibiting RNase activity until $62.5^{\circ} \mathrm{C}$, and partially at $65^{\circ} \mathrm{C}$. ' $\mathrm{RI} \mathrm{II'}$ is only effective until $60^{\circ} \mathrm{C}$ preincubation and is completely inactivated after $62.5^{\circ} \mathrm{C}$ treatment.

The results are summarized in Table 1.

Table 1. Remaining activity of different ribonuclease inhibitors after incubation at the marked temperatures.

\begin{tabular}{ccccc}
\hline & $60{ }^{\circ} \mathrm{C}$ & $62.5{ }^{\circ} \mathrm{C}$ & $65{ }^{\circ} \mathrm{C}$ & $67.5{ }^{\circ} \mathrm{C}$ \\
\hline Insect RI & + & + & + & partial \\
\hline${ }^{\prime} \mathrm{RI} \mathrm{I'}$ & + & + & partial & - \\
\hline${ }^{\prime} \mathrm{RI} \mathrm{II}$ & + & - & - & - \\
\hline${ }^{\prime} \mathrm{RI} \mathrm{III'}$ & + & + & + & - \\
\hline 'RI IV' & + & + & + & - \\
\hline
\end{tabular}

The thermostability of the RI variants was investigated using Thermal Shift Assay [18] in the absence and presence of RNase A (Figure 3). 

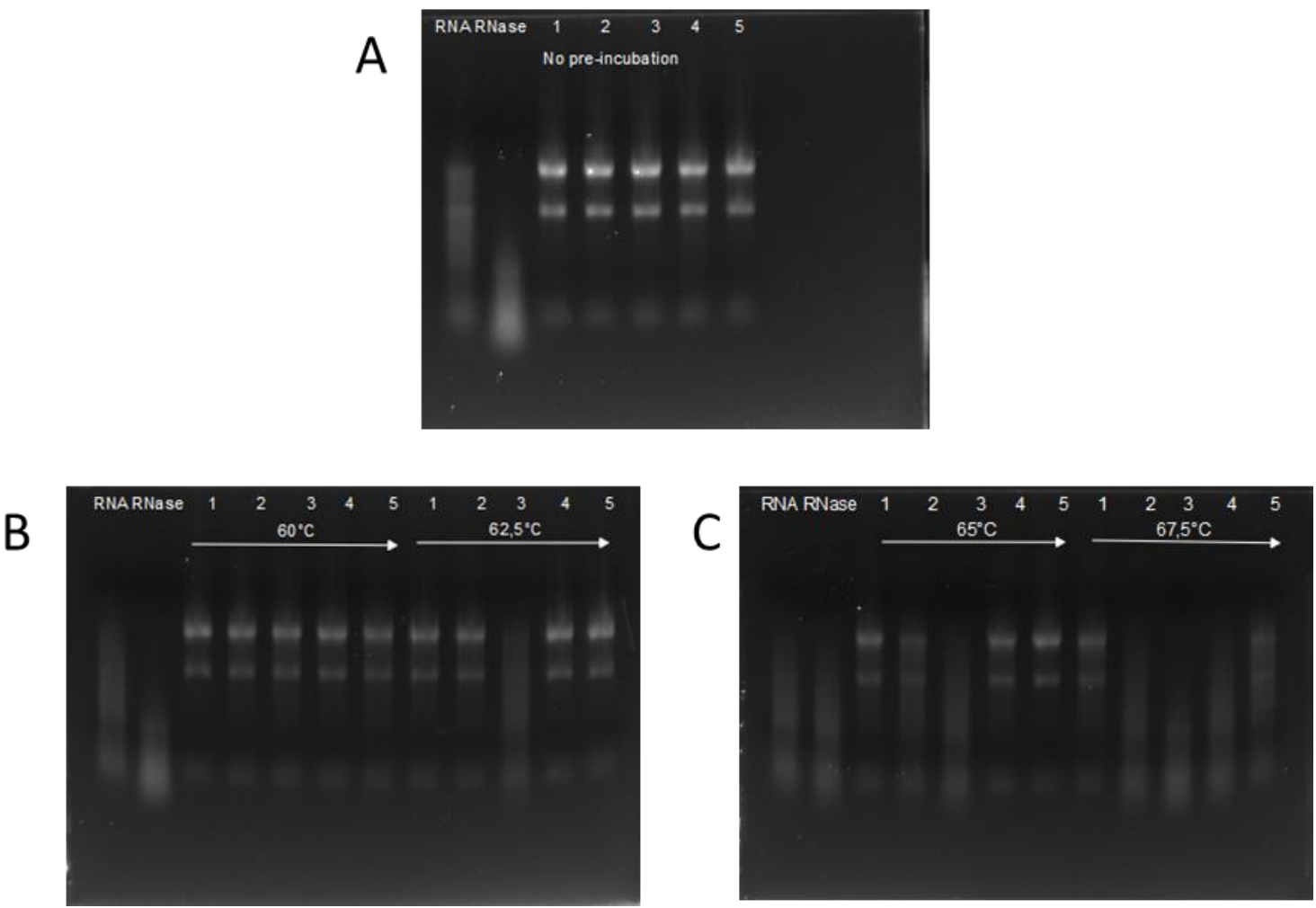

Figure 2. Remaining activity of RI after $30 \mathrm{~min}$ incubation at elevated temperatures. In each block, pre-heat temperatures are indicated. RNA is run on an e-gel after incubation with RNase A and the pre-heated RI. In all measurements, lane 1 denotes 'insect RI'; lane 2 'RI I', lane 3 'RI II'; lane 4 'RI III'; and lane 5 'RI IV'. RNA denotes the experiments without adding either RNase nor RI, and lane RNase is with added RNase, but no RI. Panel A: Remaining activity of RIs with no pre-incubation. Panel B: Remaining activity of RIs with pre-incubation at $60^{\circ} \mathrm{C}$ and $62.5^{\circ} \mathrm{C}$ on the left and right side respectively Panel C: Remaining activity of RIs with pre-incubation at $65^{\circ} \mathrm{C}$ and $67.5^{\circ} \mathrm{C}$ on the left and right side respectively.

The melting temperature of each enzyme is shown in Table 2. Interestingly, the melting temperatures of the enzymes do not directly correlate with the results derived from heat activation measurements. Without RNase A, the melting temperatures vary in the range of $50.5-54.6^{\circ} \mathrm{C}$, and the binding of RNase A increases the melting temperature by $8.6-12.4^{\circ} \mathrm{C}$ to reach $62.9-64.1^{\circ} \mathrm{C}$. The profiles of the melting curves indicate simple two-state unfolding processes, however 'RI I' shows a much lesser cooperative unfolding thermogram in complex with RNase A.

Table 2. Melting temperatures of the different ribonuclease inhibitors in the absence and presence of RNase A.

\begin{tabular}{ccc}
\hline- & \multicolumn{2}{c}{ Melting Temperature $\left({ }^{\circ} \mathbf{C}\right)$} \\
\hline Insect RI & - RNase A & + RNase A \\
\hline 'RI I' & 54.1 & 63.2 \\
\hline 'RI II' & 52.2 & 63.3 \\
\hline 'RI III' & 50.5 & 62.9 \\
\hline 'RI IV' & 54.5 & 64.1 \\
\hline
\end{tabular}


Ribonuclease inhibitor expressed in insect cells shows the highest thermostability based on the residual activity after incubation at elevated temperatures in the set of RIs examined. This behavior is of high interest for biotechnological purposes as insect-expressed RI can be used at higher reaction temperatures and for longer storage time of intact samples. The biological property behind the elevated thermotolerance can lie in the stability of the protein itself or the ribonuclease-RNase complex, as it is well known that RNase significantly stabilizes RI as it is demonstrated by the increase of melting temperature of the protein [24]. We have shown that although the RI variants show smaller differences in the melting profiles; there is no direct relationship between the biophysical thermostability and the residual activity after heat treatment of the variants. It is also worth mentioning that several variants show elevated heat resistance even above the melting temperature of the RNase-RI complex.

A new perspective could rise for insect derived RIs with the high success of mRNA vaccines [25]. A major drawback of the current mRNA-based vaccines is their storage at ultra-low temperature due to their low stability [26]. It was suggested that addition of RI to the mRNA-lipid nanoparticles could help preventing the damage of mRNA structure $[27,28]$. The addition of RI at local administration of naked self-replicating mRNA significantly improved its repeatability and efficacy [29]. We should emphasize that RI expressed in High Five cells is per se endotoxin-free, which is a high priority in vaccine development $[30,31]$.
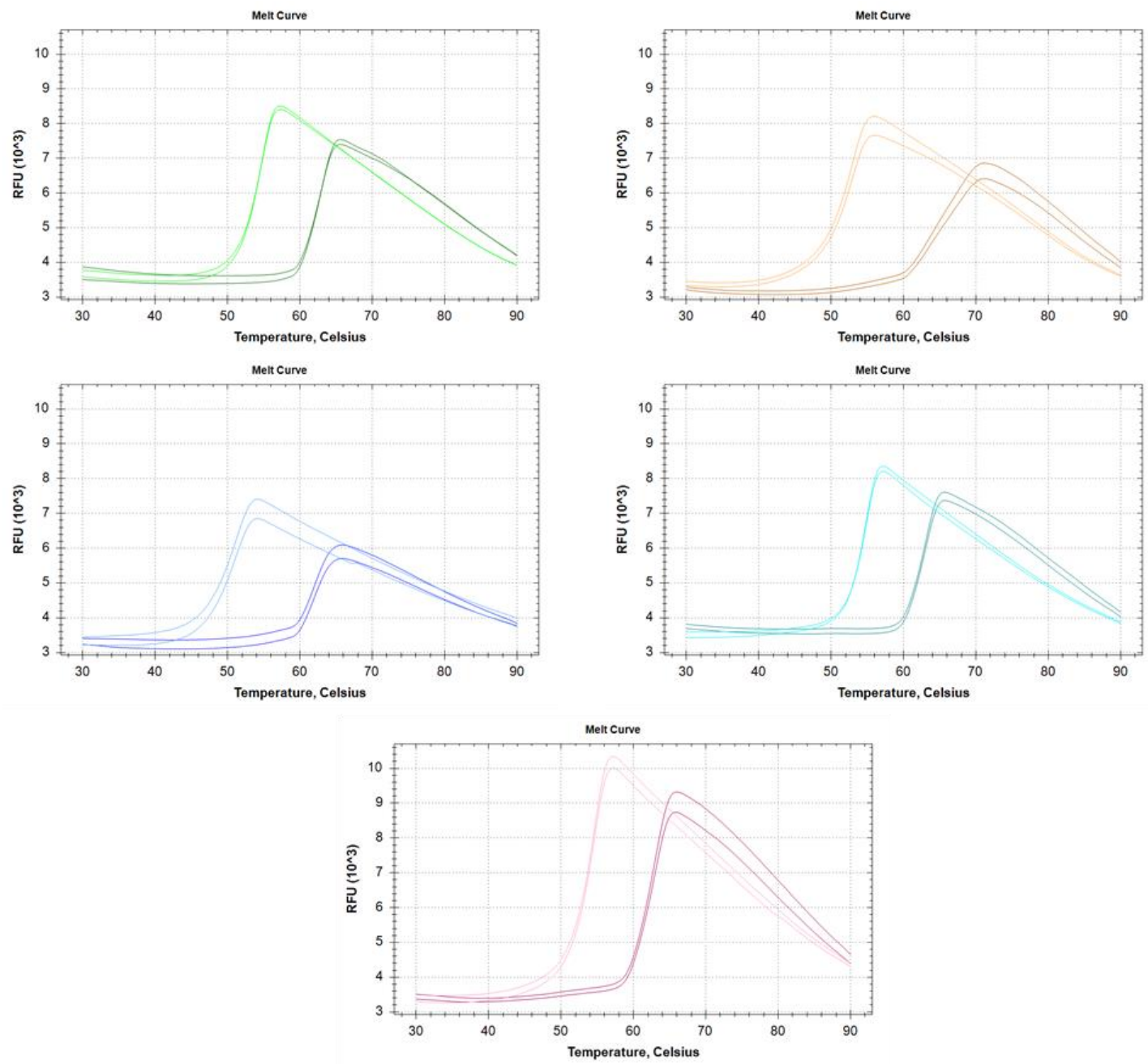

Figure 3. Melting profile of each ribonuclease inhibitor alone and in the presence of excess RNase A. Gree-Insect RI; Orange-'RI I'; Blue-'RI II'; Turquoise-'RI III'; Pink-'RI IV'. On every panel, the lighter colored curves correspond to free RI, while the darker for the RI-RNase A complex. 


\section{Conclusions}

To our knowledge, recombinant human placenta ribonuclease inhibitor was successfully produced in baculovirus/insect cell system for the first time. The volumetric quantity is comparable to that from E. coli, but the process does not require special modifications of the basic strategy of the expression system. The thermal stability of RI produced in High Five exceeds its $E$. coli counterparts making it a strong candidate to be used in biotechnological applications in the future.

Supplementary Materials: The following supporting information can be downloaded at: https: / / www.mdpi.com/article/10.3390/biom12020273/s1, Table S1: Ribonuclease inhibitor yield in a set of experiments.

Author Contributions: Conceptualization, B.F., S.C., Z.L. and I.H.; methodology, B.F. and I.H.; investigation, B.F., K.D. and A.B.; resources, S.C. and Z.L.; writing-original draft preparation, I.H.; writing-review and editing, B.F., Z.L. and I.H.; visualization, B.F.; funding acquisition, S.C. and Z.L. All authors have read and agreed to the published version of the manuscript.

Funding: This research was funded as no. 2018-1.1.1-MKI-2018-00106 implemented with the support provided from the National Research, Development and Innovation Fund of Hungary, financed under the 2018-1.1.1-MKI funding scheme.

Institutional Review Board Statement: Not applicable.

Informed Consent Statement: Not applicable.

Data Availability Statement: The data used to support the findings of this study are available from the corresponding author upon request.

Acknowledgments: We thank György Dormán for the thorough reading of the manuscript.

Conflicts of Interest: The authors declare no conflict of interest.

\section{References}

1. Kobe, B.; Deisenhofer, J. Crystal Structure of Porcine Ribonuclease Inhibitor, a Protein with Leucine-Rich Repeats. Nature 1993, 366, 751-756. [CrossRef] [PubMed]

2. Leland, P.A.; Schultz, L.W.; Kim, B.M.; Raines, R.T. Ribonuclease A Variants with Potent Cytotoxic Activity. Proc. Natl. Acad. Sci. USA 1998, 95, 10407-10412. [CrossRef] [PubMed]

3. Klink, T.A.; Vicentini, A.M.; Hofsteenge, J.; Raines, R.T. High-Level Soluble Production and Characterization of Porcine Ribonuclease Inhibitor. Protein. Expr. Purif. 2001, 22, 174-179. [CrossRef] [PubMed]

4. Guo, W.; Cao, L.; Jia, Z.; Wu, G.; Li, T.; Lu, F.; Lu, Z. High Level Soluble Production of Functional Ribonuclease Inhibitor in Escherichia Coli by Fusing It to Soluble Partners. Protein. Expr. Purif. 2011, 77, 185-192. [CrossRef]

5. Siurkus, J.; Neubauer, P. Reducing Conditions Are the Key for Efficient Production of Active Ribonuclease Inhibitor in Escherichia Coli. Microb. Cell Fact. 2011, 10, 31. [CrossRef]

6. Vicentini, A.M.; Kieffer, B.; Matthies, R.; Meyhack, B.; Hemmings, B.A.; Stone, S.R.; Hofsteenge, J. Protein Chemical and Kinetic Characterization of Recombinant Porcine Ribonuclease Inhibitor Expressed in Saccharomyces Cerevisiae. Biochemistry 1990, 29, 8827-8834. [CrossRef]

7. Park, J.-H.; Hwang, I.-S.; Kim, K.-I.; Lee, J.-M.; Park, Y.-M.; Park, C.-H.; Chung, I.S. Functional Expression of Recombinant Human Ribonuclease/Angiogenin Inhibitor in Stably Transformed Drosophila Melanogaster S2 Cells. Cytotechnology 2008, 57, 93-99. [CrossRef]

8. Fominaya, J.M.; Hofsteenge, J. Inactivation of Ribonuclease Inhibitor by Thiol-Disulfide Exchange. J. Biol. Chem. 1992, 267, 24655-24660. [CrossRef]

9. Kim, B.M.; Schultz, L.W.; Raines, R.T. Variants of Ribonuclease Inhibitor That Resist Oxidation. Protein. Sci. 1999, 8, 430-434. [CrossRef]

10. Blackburn, P.; Wilson, G.; Moore, S. Ribonuclease Inhibitor from Human Placenta. Purification and Properties. J. Biol. Chem. 1977, 252, 5904-5910. [CrossRef]

11. Lee, F.S.; Vallee, B.L. Expression of Human Placental Ribonuclease Inhibitor in Escherichia Coli. Biochem. Biophys. Res. Commun. 1989, 160, 115-120. [CrossRef]

12. Panula-Perälä, J.; Siurkus, J.; Vasala, A.; Wilmanowski, R.; Casteleijn, M.G.; Neubauer, P. Enzyme Controlled Glucose AutoDelivery for High Cell Density Cultivations in Microplates and Shake Flasks. Microb. Cell Fact. 2008, 7, 31. [CrossRef] 
13. Threat Assessment Brief: Emergence of SARS-CoV-2 B.1.617 Variants in India and Situation in the EU/EEA. Available online: https: / www.ecdc.europa.eu/en/publications-data/threat-assessment-emergence-sars-cov-2-b1617-variants (accessed on 3 December 2021).

14. Threat Assessment Brief: Implications of the Emergence and Spread of the SARS-CoV-2 B.1.1. 529 Variant of Concern (Omicron) for the EU/EEA. Available online: https:/ / www.ecdc.europa.eu/en/publications-data/threat-assessment-brief-emergence-sarscov-2-variant-b.1.1.529 (accessed on 3 December 2021).

15. Jarvis, D.L. Baculovirus-Insect Cell Expression Systems. Methods Enzymol. 2009, 463, 191-222. [CrossRef] [PubMed]

16. Ellis, E.L.; Delbrück, M. The Growth of Bacteriophage. J. Gen. Physiol. 1939, 22, 365-384. [CrossRef] [PubMed]

17. Hopkins, R.; Esposito, D. A Rapid Method for Titrating Baculovirus Stocks Using the Sf-9 Easy Titer Cell Line. Biotechniques 2009, 47, 785-788. [CrossRef] [PubMed]

18. Pantoliano, M.W.; Petrella, E.C.; Kwasnoski, J.D.; Lobanov, V.S.; Myslik, J.; Graf, E.; Carver, T.; Asel, E.; Springer, B.A.; Lane, P.; et al. High-Density Miniaturized Thermal Shift Assays as a General Strategy for Drug Discovery. J. Biomol. Screen 2001, 6, 429-440. [CrossRef] [PubMed]

19. Peleg, Y.; Prabahar, V.; Bednarczyk, D.; Unger, T. Harnessing the Profinity EXact ${ }^{\mathrm{TM}}$ System for Expression and Purification of Heterologous Proteins in E. Coli. Methods Mol. Biol. 2017, 1586, 33-43. [CrossRef]

20. Ruan, B.; Fisher, K.E.; Alexander, P.A.; Doroshko, V.; Bryan, P.N. Engineering Subtilisin into a Fluoride-Triggered Processing Protease Useful for One-Step Protein Purification. Biochemistry 2004, 43, 14539-14546. [CrossRef] [PubMed]

21. Somogyi, M.; Szimler, T.; Baksa, A.; Végh, B.M.; Bakos, T.; Paréj, K.; Ádám, C.; Zsigmond, Á.; Megyeri, M.; Flachner, B.; et al. A Versatile Modular Vector Set for Optimizing Protein Expression among Bacterial, Yeast, Insect and Mammalian Hosts. PLoS ONE 2019, 14, e0227110. [CrossRef] [PubMed]

22. Hitchman, R.B.; Possee, R.D.; Crombie, A.T.; Chambers, A.; Ho, K.; Siaterli, E.; Lissina, O.; Sternard, H.; Novy, R.; Loomis, K.; et al. Genetic Modification of a Baculovirus Vector for Increased Expression in Insect Cells. Cell Biol. Toxicol. 2010, 26, 57-68. [CrossRef]

23. Rieffel, S.; Roest, S.; Klopp, J.; Carnal, S.; Marti, S.; Gerhartz, B.; Shrestha, B. Insect Cell Culture in Reagent Bottles. MethodsX 2014, 1,155-161. [CrossRef]

24. Lomax, J.E.; Bianchetti, C.M.; Chang, A.; Phillips, G.N.; Fox, B.G.; Raines, R.T. Functional Evolution of Ribonuclease Inhibitor: Insights from Birds and Reptiles. J. Mol. Biol. 2014, 426, 3041-3056. [CrossRef]

25. Sahin, U.; Muik, A.; Derhovanessian, E.; Vogler, I.; Kranz, L.M.; Vormehr, M.; Baum, A.; Pascal, K.; Quandt, J.; Maurus, D.; et al. COVID-19 Vaccine BNT162b1 Elicits Human Antibody and TH1 T Cell Responses. Nature 2020, 586, 594-599. [CrossRef]

26. Schoenmaker, L.; Witzigmann, D.; Kulkarni, J.A.; Verbeke, R.; Kersten, G.; Jiskoot, W.; Crommelin, D.J.A. MRNA-Lipid Nanoparticle COVID-19 Vaccines: Structure and Stability. Int. J. Pharm. 2021, 601, 120586. [CrossRef]

27. Borah, P.; Deb, P.K.; Al-Shar'i, N.A.; Dahabiyeh, L.A.; Venugopala, K.N.; Singh, V.; Shinu, P.; Hussain, S.; Deka, S.; Chandrasekaran, B.; et al. Perspectives on RNA Vaccine Candidates for COVID-19. Front. Mol. Biosci. 2021, 8, 30. [CrossRef] [PubMed]

28. Wang, F.; Kream, R.M.; Stefano, G.B. An Evidence Based Perspective on MRNA-SARS-CoV-2 Vaccine Development. Med. Sci. Monit. 2020, 26, e924700-1-e924700-8. [CrossRef] [PubMed]

29. Huysmans, H.; Temmerman, J.D.; Zhong, Z.; Cafferty, S.M.; Combes, F.; Haesebrouck, F.; Sanders, N.N. Improving the Repeatability and Efficacy of Intradermal Electroporated Self-Replicating MRNA. Mol. Ther.-Nucleic Acids 2019, 17, 388-395. [CrossRef]

30. Brito, L.A.; Singh, M. Acceptable Levels of Endotoxin in Vaccine Formulations during Preclinical Research. J. Pharm. Sci. 2011, 100, 34-37. [CrossRef]

31. Whitley, J.; Zwolinski, C.; Denis, C.; Maughan, M.; Hayles, L.; Clarke, D.; Snare, M.; Liao, H.; Chiou, S.; Marmura, T.; et al Development of MRNA Manufacturing for Vaccines and Therapeutics: MRNA Platform Requirements and Development of a Scalable Production Process to Support Early Phase Clinical Trials. Transl. Res. 2021, in press. [CrossRef] [PubMed] 